\title{
The EC-Scandinavian agricultural trade changes - causes and consequences
}

\author{
TUOMAS KUHMONEN
}

Pellervo Economic Research Institute, Revontulentie 8, 02100 Espoo, Finland

\section{DIRK STRIJKER}

State University Groningen, P.O.Box 800, 9700 AV Groningen, The Netherlands

\begin{abstract}
This article examines the changes in the mutual agro-food trade between the EC and Scandinavian countries - Finland, Norway and Sweden - in 1960-85 by using the concept of "Revealed Comparative Advantage". The agricultural policy actions of the EC have weakened the mutual trading position of Scandinavia very strongly in basic temperate agricultural products but improved it in other types of agro-food products. The massive supports and trade regulations of the EC have also increased its mutual competitiveness in agrofood compared to all traded items. In recent years a redirection of agricultural policy has started in the EC from price support and increasing productivity to production cutbacks and direct income support. This seems to be the same path as the Scandinavian countries had to take earlier.
\end{abstract}

\section{Introduction}

The external trade effects of the Common Agricultural Policy of the EC (CAP) have been widely examined and criticized (ANDERSON and TYERS, 1984; Bureau of Agricultural Economics, 1985; KNOX, 1986). The spotlight of discussions has mainly been devoted to the effects of the CAP on two groups of countries: the powerful agricultural producers and the poor developing countries. This article analyses the changes in the agro-food trade between the EC and the three Scandinavian countries - Finland, Norway and Sweden.
Quantitative developments in mutual trade are investigated and combined with the development of the agricultural policy of both the EC and the Nordic countries. The methodology of the analysis is explained in paragraph 2, whereas the actual trade transformations are described in paragraph 3 . The connection between the CAP and mutual trade changes is discussed in the next paragraph, followed by the presentation of some features of Scandinavian agricultural policy changes influenced by external agro-food trade positions. In the last paragraph some conclusions and future prospects are presented. 


\section{Methodology}

The analysis of trade changes is carried out on three levels. Firstly, a general description of mutual trade is given by simple trade shares (value basis). Secondly, a systematic analysis of trade is done by using the concept of "Revealed Comparative Advantage" (RCA) introduced by BaLASSA (1965). The transformed RCA-index is applied separately to Scandinavian country imports from, and exports to, the EC-10, again in values, thus including possible terms of trade effects. Different product groups inside the agro-food products $^{1}$, and agro-food products vs. other products are analyzed separately. The RCAindex is constructed as follows:

$$
R C A=100 \times \frac{X_{j(E C)} / X_{j(n)}}{X_{t(E C)} / X_{t(n)}},
$$

where $\mathrm{X}_{\mathrm{j}(\mathrm{EC})}$ is the value of imports of product group $j$ from the EC, $X_{j(n)}$ is the total value of imports of product group $\mathrm{j}, \mathrm{X}_{\mathrm{t}(\mathrm{EC})}$ is the value of total imports of the reference group from the $\mathrm{EC}$, and $\mathrm{X}_{\mathrm{t}(\mathrm{n})}$ is the total value of imports of the reference group. In exports to the EC the shares are defined in the same way. When the value of the imports index exceeds 100 , the EC has "Revealed Comparative Advantage" in Scandinavian imports of the product group in question. When the value of the exports index exceeds 100, then the Scandinavian country has "RCA" in exports to the $\mathrm{EC}$ for the product group in question. So, in both cases the point of view is Scandinavian, reducing some of the deficiencies of this approach (substitutes, grades and qualities, changes in freight rates etc. as discussed by BaLASSA (1965) and JoHns (1985)). The EC-10 member countries are included over the research period $1960-85$, which makes it possible to visualize the changes caused by the enlargement of the EC. Despite of the many deficiencies of this kind of measuring, this in-

1 Includes SITC-sections and divisions 0,1,21,22,4. The data are based on the national trade statistics of the Scandinavian countries. dex can be used to monitor mutual shifts in relative "gross competitiveness" of different product groups.

On the third level of analysis the index for "Relative Trading Power" (RTP) is introduced. This index is calculated by dividing the RCA-index of exports by the respective RCA-index of imports (base-period $=100$ ). In this way, the simultaneous changes in the relative mutual trading power both in exports and imports (from the Scandinavian point of view) can be monitored as a single figure. So, if the RCA of a Scandinavian country increases in relation to the RCA of the EC in a certain product group, the RTP-index numbers will increase - and vice versa.

The RTP-index can be used to describe systematically the degree of pressure transmitted from the EC to Scandinavian countries through changes in mutual trade. As a gross index it also includes the impact of the agricultural policy of the EC. The quantitative connection between the CAP and trade changes is verified by means of a regression analysis (OLS). Then, the share of the EC in trade or the RCA- or RTP-indices are used as a dependent variable. The introduction of the CAP in the early 1960's and the enlargement of the EC in 1973 (to include Denmark, Ireland and the United Kingdom) were selected to represent concrete actions of the agricultural policy changes of the EC. Both of these were described by dummy variables (DCAP and DENL) to show the shifts in trade shares; no additional independent variables were used.

Finally, the indicated trade changes are related qualitatively to the changes in the agricultural policy of Scandinavian countries caused by these trade changes.

\section{Results}

\subsection{Trade changes $1960-85$}

The share of the EC in total agro-food imports of Scandinavian countries has increased steadily between 1960 and 1985 (Table 1). As such, the share of the EC is highest in Sweden, 
Table 1. Agro-food trade of Scandinavian countries in 1960/65 (average) and 1980/85 (average) by source and destination, percentage shares in imports and exports values.

\begin{tabular}{|c|c|c|c|c|c|c|c|c|}
\hline \multirow{2}{*}{$\begin{array}{l}\text { Country } \\
\text { Flow } \\
\text { Years }\end{array}$} & \multicolumn{2}{|c|}{$\begin{array}{l}\text { Finland } \\
\text { imports }\end{array}$} & \multicolumn{2}{|c|}{ exports } & \multicolumn{2}{|c|}{$\begin{array}{l}\text { Norway } \\
\text { imports }\end{array}$} & \multicolumn{2}{|c|}{ exports } \\
\hline & $60 / 65$ & $80 / 85$ & $60 / 65$ & $80 / 85$ & $60 / 65$ & $80 / 85$ & $60 / 65$ & $80 / 85$ \\
\hline \multicolumn{9}{|c|}{ Source or destination: } \\
\hline EC-8 & 8.8 & 12.2 & 24.7 & 21.3 & 9.4 & 16.0 & 26.8 & 22.2 \\
\hline Denmark & 3.7 & 4.1 & 1.1 & 2.1 & 5.7 & 10.9 & 2.2 & 5.2 \\
\hline United Kingdom & 2.0 & 4.0 & 29.2 & 3.5 & 6.4 & 5.4 & 19.2 & 12.8 \\
\hline EC-10 & 14.5 & 20.3 & 55.0 & 26.9 & 21.5 & 32.3 & 48.2 & 40.2 \\
\hline EFTA & 4.8 & 15.2 & 9.0 & 17.1 & 4.5 & 16.2 & 14.7 & 23.8 \\
\hline USA & 9.6 & 11.4 & 9.1 & 10.8 & 19.8 & 14.4 & 10.3 & 11.3 \\
\hline USSR & 17.4 & 0.8 & 14.0 & 24.0 & 3.3 & 0.7 & 4.9 & 0.2 \\
\hline Other countries & 53.7 & 52.3 & 12.9 & 21.2 & 50.9 & 36.4 & 21.9 & 24.5 \\
\hline TOTAL & 100.0 & 100.0 & 100.0 & 100.0 & 100.0 & 100.0 & 100.0 & 100.0 \\
\hline
\end{tabular}

\begin{tabular}{lrrrrr}
\hline \multirow{2}{*}{$\begin{array}{l}\text { Country } \\
\text { Flow }\end{array}$} & \multicolumn{2}{c}{$\begin{array}{c}\text { Sweden } \\
\text { imports }\end{array}$} & & \multicolumn{2}{c}{ exports } \\
\cline { 2 - 3 } \cline { 5 - 6 } Years & $60 / 65$ & $80 / 85$ & & $60 / 65$ & $80 / 85$ \\
\hline Source or destination: & & & & & \\
EC-8 & 14.7 & 20.7 & & 36.4 & 22.2 \\
Denmark & 11.0 & 10.3 & & 6.0 & 12.1 \\
United Kingdom & 1.8 & 3.9 & & 17.3 & 4.3 \\
EC-10 & 27.5 & 34.9 & & 59.7 & 38.6 \\
EFTA & 6.3 & 14.9 & & 9.3 & 21.7 \\
USA & 11.8 & 7.8 & & 10.0 & 7.2 \\
USSR & 2.4 & 0.3 & & 0.3 & 10.0 \\
Other countries & 52.0 & 42.1 & & 20.7 & 22.5 \\
TOTAL & 100.0 & 100.0 & & 100.0 & 100.0 \\
\hline
\end{tabular}

Note: EC-8 = Belgium, France, Germany, Italy, Luxembourg and the Netherlands in 1960/65, plus Ireland and Greece in 1980/85.

EC-10 $=$ the countries above, plus Denmark and the United Kingdom.

EFTA = Austria, Finland, Norway, Portugal, Sweden and Switzerland in 1960/65, plus Iceland in 1980/85; excluding the country in question. For Sweden Austria and Portugal are excluded in earlier years.

the country with a relatively a liberal trade policy.

In the agro-food exports of Finland and Sweden the share of the EC in turn has decreased radically. In the exports of Norway, fish has such a dominating position that this country has not suffered from the trade barriers of the EC to such a large extent. The closure of the British market for non-EC-exporters in 1973 as a consequence of the ECmembership was drastic - e.g. in Finland the value of agro-food exports to the UK dropped to one-fourth between 1972 and 1973 .

The RCA-index applied to agro-food imports from the EC indicates values over 100 in dairy products, in cereals, in feedingstuffs and in beverages and tobacco in all Scandinavian countries (Table 2). As such, the EC has achieved a higher share than the average in imports of these product groups. Clearly below the average are falling the product groups of oilseeds, fish, fruit and vegetables, and tea and coffee. Among the most common temperate agricultural products the trend of the index has increased in crop products but decreased in livestock products.

All the Scandinavian countries have a RCAindex value above 100 in the 1980's in exports of fish, coffee and tea, oilseeds and oils and fats, implying that they are able to export 
Table 2. RCA-index per product group in Scandinavian imports from and exports to the EC-10 in 1960/65 (average) and 1980/85 (average).

\begin{tabular}{|c|c|c|c|c|c|c|}
\hline \multirow{2}{*}{$\begin{array}{l}\text { Country } \\
\text { Flow } \\
\text { Years }\end{array}$} & \multicolumn{2}{|c|}{$\begin{array}{l}\text { Finland } \\
\text { imports }\end{array}$} & \multicolumn{2}{|c|}{ exports } & \multicolumn{2}{|c|}{$\begin{array}{l}\text { Norway } \\
\text { imports }\end{array}$} \\
\hline & $60 / 65$ & $80 / 85$ & $60 / 65$ & $80 / 85$ & $60 / 65$ & $80 / 85$ \\
\hline \multicolumn{7}{|l|}{ Agro-food product group: } \\
\hline Live animals $(00)$ & 418 & 146 & 3 & 41 & . & . \\
\hline Meat $(01)$ & 470 & 177 & 51 & 10 & 193 & 152 \\
\hline Dairy + eggs (02) & 357 & 447 & 111 & 73 & 345 & 237 \\
\hline Fish (03) & 74 & 36 & 8 & 128 & 285 & 79 \\
\hline Cereals (04) & 53 & 126 & 58 & 65 & 60 & 106 \\
\hline Fruit + vegetables (05) & 125 & 91 & 119 & 98 & 82 & 79 \\
\hline Sugar $(06)$ & 17 & 93 & 32 & 73 & 298 & 217 \\
\hline Coffee + tea $(07)$ & 40 & 59 & 21 & 127 & 36 & 55 \\
\hline Feedingstuffs (08) & 44 & 180 & 163 & 21 & 50 & 106 \\
\hline Miscellaneous food (09) & 346 & 211 & 53 & 27 & 245 & 204 \\
\hline Beverages + tobacco (1) & 209 & 132 & 8 & 14 & 136 & 131 \\
\hline Hides + skins (21) & 151 & 218 & 85 & 164 & 163 & 102 \\
\hline Oilseeds (22) & 19 & 13 & - & 339 & 4 & 5 \\
\hline Oils + fats (4) & 408 & 193 & 90 & 243 & 139 & 114 \\
\hline
\end{tabular}

\begin{tabular}{|c|c|c|c|c|c|c|}
\hline \multirow{2}{*}{$\begin{array}{l}\text { Country } \\
\text { Flow } \\
\text { Years }\end{array}$} & \multicolumn{2}{|c|}{$\begin{array}{l}\text { Norway } \\
\text { exports }\end{array}$} & \multicolumn{2}{|c|}{$\begin{array}{l}\text { Sweden } \\
\text { imports }\end{array}$} & \multicolumn{2}{|c|}{ exports } \\
\hline & $60 / 65$ & $80 / 85$ & $60 / 65$ & $80 / 85$ & $60 / 65$ & $80 / 85$ \\
\hline \multicolumn{7}{|l|}{ Agro-food product group: } \\
\hline Live animals $(00)$ & & . & 163 & 124 & 131 & 72 \\
\hline Meat $(01)$ & 134 & 75 & 213 & 84 & 146 & 170 \\
\hline Dairy + eggs (02) & 150 & 22 & 256 & 188 & 102 & 36 \\
\hline Fish (03) & 80 & 112 & 131 & 86 & 71 & 167 \\
\hline Cereals (04) & 55 & 60 & 90 & 169 & 115 & 41 \\
\hline Fruit + vegetables $(05)$ & 72 & 94 & 113 & 80 & 124 & 139 \\
\hline Sugar (06) & 117 & 156 & 139 & 195 & 15 & 58 \\
\hline Coffee + tea (07) & 127 & 137 & 19 & 49 & 110 & 106 \\
\hline Feedingstuffs (08) & 157 & 70 & 150 & 116 & 73 & 34 \\
\hline Miscellaneous food (09) & 51 & 21 & 110 & 149 & 71 & 82 \\
\hline Beverages + tobacco $(1)$ & 41 & 66 & 136 & 141 & 123 & 49 \\
\hline Hides + skins (21) & 94 & 87 & 63 & 138 & 61 & 182 \\
\hline Oilseeds (22) & 0 & 119 & 4 & 18 & 97 & 186 \\
\hline Oils + fats (4) & 120 & 123 & 114 & 167 & 97 & 98 \\
\hline
\end{tabular}

Note: Between brackets SITC-codes.

For statistical reasons group SITC-09 includes also group SITC-00 for Norway; for SITC-07 in Norway the figure in earlier years is based on year 1965 only.

these products to the $\mathrm{EC}$ relatively more than on the average. Finland and Sweden also indicate high index numbers in exports of fruit and vegetables and hides and skins. The index numbers for basic temperate products fall below the average of 100. Between 1960/65 and 1980/85 the index has decreased for these product groups, although the need for exports has increased along with surpluses in Scandinavia.
The RCA-index applied to the total mutual trade suggests that the share of the EC in imports of agro-food products of Scandinavia is lower than its share in total imports of the Scandinavian countries. Apart from this "revealed disadvantage", the index numbers have increased remarkably in all Scandinavian countries since the early 1960 's. This means that the EC has been able to push through the Scandinavian import restrictions on agro-food 
products much more succesfully than on manufactured goods and non-food raw materials.

In the days before the CAP both Finland and Sweden were able to export to the EC relatively more agro-food products than other products. In all these countries the value of RCA-index in exports has decreased over time, however. So, the Scandinavian countries have managed relatively better in the exports of other than agro-food products. As such, both these indices refer to the deteriorating mutual competitive position of the Scandinavian agricultural sector (gross of trade measures and supports) in relation to the agricultural sector of the EC.

The RTP-index shows that the Scandinavian countries have increased their relative trading power with respect to the EC most in fish, and oils and fats (Table 3). Two out of the three countries have increased their index numbers in sugar products, beverages and tobacco, hides and skins, oilseeds, and oils and fats. The relative trading power of Scandinavia has decreased in dairy products, cereals, feedingstuffs and miscellaneous food products (Finland and Norway also in meat products).

The progress of the EC in Scandinavian imports and the simultaneous relative contrac-

Table 3. RTP-index in 1980/85 (average), when 1960/65 (average) $=100$.

\begin{tabular}{lrrr}
\hline Product group & Finland & Norway & Sweden \\
\hline Live animals (00) & 1.350 & & 71 \\
Meat (01) & 55 & 62 & 311 \\
Dairy + eggs (02) & 47 & 21 & 48 \\
Fish (03) & 3.236 & 450 & 351 \\
Cereals (04) & 45 & 57 & 19 \\
Fruit + vegetables (05) & 116 & 137 & 159 \\
Sugar (06) & 37 & 180 & 333 \\
Coffee + tea (07) & 402 & 84 & 38 \\
Feedingstuffs (08) & 3 & 14 & 67 \\
Miscellaneous food (09) & 73 & 48 & 86 \\
Beverages + tobacco (1) & 400 & 152 & 39 \\
Hides + skins (21) & 132 & 3 & 131 \\
Oilseeds (22) & $\infty$ & $\infty$ & 42 \\
Oils + fats (4) & 591 & 127 & 67 \\
\hline
\end{tabular}

Note: Between brackets SITC-codes. tion of Scandinavian exports to the EC have decreased the relative trading power of Scandinavia in agro-food products compared to all products. The relative mutual trading power of Finland has decreased most, followed by Norway and Sweden.

\subsection{CAP as a cause}

The reviewed trade changes show that there are large differences among the agro-food product groups, on the one hand, and between the agro-food products and other products, on the other hand, in the mutual trade between the EC and Scandinavia. Most of these differences can be shown to originate in the agricultural policy actions of the EC. This is done by a simple regression analysis (OLS) with DCAP and DENL as dummies (see notes of Table 4$)^{2}$. For imports in Scandinavian coutries we used:

EC-import share $=$ Constant + a DCAP +

b DENL + e

and for exports from these countries:

EC-export share $=$ Constant + c DCAP + d DENL + e.

The results showed that both the introduction of the CAP and the enlargement of the Community have tended to increase the share of the EC in imports, though the variables are not very significant. The combined impact is most significant in Norway, which is the only Scandinavian net importer of temperate agricultural products. The R-square varied between 0.30 and 0.59 .

When applied to exports, the analysis shows the trade diversion effect of the CAP to have been strongest on Finnish agro-food exports (decrease of the EC-share by 28 percentage points), followed by Sweden ( 23 percentage points) and Norway (5 percentage points). The moderate impact on Norway has its grounds in the very small share of temperate products in Norwegian exports. Most of the variables are significant at the level of 0.001 and the Rsquare lies between 0.63 and 0.91 . The impact

\footnotetext{
2 See Kunmonen (1991) for more detailed results.
} 
of the CAP is most significant in Finland, because her dairy products exports constituted some 60 per cent of total agro-food exports in the 1960's when the dairy support and trade policy of the EC began ${ }^{3}-$ compared to some 5 per cent in Norway and Sweden. In Norway and Sweden instead the impact of the new member countries is dominating.

The increase in self-sufficiency ratios in the EC (Commission of the European Communities) stimulated (subsidized) exports, which apparently affected the nearby Scandinavian markets for temparate zone (especially arable) agricultural products, although the parallel developments in Scandinavia have slightly reduced this effect in meat and dairy products. The EC policy has caused a clear trade diversion effect of these same products from the Scandinavian origins - despite the respective degree of regulations, surpluses and supports over there. This would suggest the difference in size and resources to have influenced the diverging trading positions and powers of the parties, though at the same time realizing the principle of relative comparative advantage in international trade to some extent.

Another interesting question is if the massive supports of the EC have changed its relative trading position in agro-food compared to other products. This can be highlighted by means of the RCA- and RTP-indices. When applied to the RCA-index of Scandinavian agro-food vs. total imports from the EC, the regression analysis shows positive effects of both the CAP-dummy and the enlargement dummy (See Table 4)

Thus it can be argued that the agricultural policy of the EC has put an increased pressure on the Scandinavian agricultural sector to replace domestic production by increased imports from the EC and simultaneously decrease the import shares of third countries despite of the strict Scandinavian agro-food import restrictions and quite free mutual trade of manufactured goods. This impact has been

\footnotetext{
${ }^{3}$ In dairy exports, the impact of the two dummies varies between -44 and -62 percentage points, R-square $0.84-0.93$.
}

strongest in Finland and Norway and weakest in Sweden, which is most competitive of these countries in temperate products.

When applied to the RCA-index of agrofood vs. total exports to the EC, the analysis confirms the results of the trade shares considerations (Table 5). The enlargement-dummy takes the bulk of the negative impact of the depending variable (R-square $0.53-0.86$ ).

In table 6 the results of the RTP-estimation are shown for the relation between agro-food and total trade. The mutual trading position of Finland suffered most from the introduction of the CAP in the 1960's, followed by Norway and Sweden (DCAP in table 6). The membership of the new countries in 1973 had major effects on Norwegian and Swedish trading positions (DENL in table 6). The combined total impact has been strongest in Finland, followed by Norway and Sweden again in line with the relative competitiveness of the temperate agricultural sectors of the countries. So, the relatively small Scandinavian countries have seen their mutual trading power deteriorate in agro-food products compared to the power of the large EC.

\subsection{Policy changes in Scandinavia and the EC}

Of course the changes in the mid-sixties and the enlargement of the EC did not influence the agricultural policies of the Scandinavian countries immediately. Nevertheless, the pressure of the EC certainly redirected Scandinavian agricultural exports to less attractive and more expensive markets. At a later stage more fundamental policy decisions were made in all the three Scandinavian countries (production cut-backs, either voluntary or obliged: quota). In all three countries the regionalisation of agricultural policy became more prominent.

It can be concluded that in many respects the development of the Common Agricultural Policy has functioned as an accelerator for fundamental changes in the agricultural policies of the Scandinavian countries.

In terms of the development of production, 
self-sufficiency ratios and international critizism, the position of the EC was not very different from that of Scandinavian countries. But because of the unequal trading and political power, the large EC could stand the fun- damental pressure to change of its policy much longer, at the cost of, for instance, the Scandinavian countries.

Nevertheless, the pressure on the EC agricultural policy could only be pushed ahead

Table 4. Regression analysis results. RCA-index in Scandinavian agro-food vs. total imports from the EC in 1960 -85 .

\begin{tabular}{|c|c|c|c|c|c|}
\hline \multicolumn{6}{|c|}{ Depending variable: RCA-index, agro-food vs. total imports } \\
\hline Country & $\begin{array}{c}\text { Constant } \\
\text { (t-value) }\end{array}$ & $\begin{array}{c}\text { DCAP } \\
\text { (t) }\end{array}$ & $\begin{array}{c}\text { DENL } \\
\text { (t) }\end{array}$ & $\mathbf{R}^{2}$ & $\begin{array}{l}\text { Stand. } \\
\text { error }\end{array}$ \\
\hline Finland & $\begin{array}{l}29.3^{* * *} \\
(8.8)\end{array}$ & $\begin{array}{l}10.1 \\
(2.4)\end{array}$ & $\begin{array}{l}13.7^{* * * *} \\
(4.1)\end{array}$ & 0.645 & 7.4 \\
\hline Norway & $\begin{array}{l}44.4^{* * * *} \\
(15.2)\end{array}$ & $\begin{array}{l}12.7^{* * *} \\
(3.4)\end{array}$ & $\begin{array}{l}10.6^{* * *} \\
(3.6)\end{array}$ & 0.675 & 6.6 \\
\hline Sweden & $\begin{array}{l}50.2^{* * * *} \\
(36.3)\end{array}$ & $\begin{array}{l}8.8^{* * * *} \\
(5.0)\end{array}$ & $\begin{array}{l}5.2^{* * *} \\
(3.7)\end{array}$ & 0.766 & 3.1 \\
\hline
\end{tabular}

Note: DCAP: Dummy variable, the effect of the CAP (1965).

DENL: Dummy variable, the effect of the new member countries Denmark and the United Kingdom (1973). The significance is given as: ${ }^{* * *} \mathrm{p}<0.1$ per cent, ${ }^{* *} \mathrm{p}<0.5$ per cent, ${ }^{*} \mathrm{p}<1.0$ per cent.

Table 5. Regression analysis results: RCA-index in Scandinavian agro-food vs. total exports to the EC in 1960 -85 .

\begin{tabular}{lccccc}
\hline Depending variable: RCA-index, agro-food vs. total imports & & & \\
\hline Country & $\begin{array}{l}\text { Constant } \\
(\mathrm{t}-\mathrm{value})\end{array}$ & $\begin{array}{c}\text { DCAP } \\
(\mathrm{t})\end{array}$ & $\begin{array}{c}\text { DENL } \\
(\mathrm{t})\end{array}$ & $\mathrm{R}^{2}$ & $\begin{array}{c}\text { Stand. } \\
\text { error }\end{array}$ \\
\hline Finland & $\begin{array}{l}105.7^{* * *} \\
(20.8)\end{array}$ & -13.0 & $-16.0^{* *}$ & 0.532 & 11.4 \\
Norway & $(-2.0)$ & $(-3.1)$ & & 9.597 & 9.0 \\
& $82.9^{* * *}$ & 4.2 & $-22.1^{* * *}$ & & 6.9 \\
Sweden & $(20.5)$ & $(0.8)$ & $(-5.4)$ & 0.860 & 6.9 \\
\hline
\end{tabular}

See note Table 4.

Table 6. Regression analysis of RTP-index $(1960=100)$ of agro-food vs. all products.

\begin{tabular}{lccccc}
\hline Depending variable: RTP-index, agro-food vs. all products & & \\
\hline Country & $\begin{array}{c}\text { Constant } \\
\text { (t-value) }\end{array}$ & $\begin{array}{c}\text { DCAP } \\
(\mathrm{t})\end{array}$ & $\begin{array}{c}\text { DENL } \\
(\mathrm{t})\end{array}$ & $\mathrm{R}^{2}$ & $\begin{array}{c}\text { Stand. } \\
\text { error }\end{array}$ \\
\hline Finland & $\begin{array}{l}84.3^{* * *} \\
(17.1)\end{array}$ & $\begin{array}{l}-29.9^{* * *} \\
(-4.8)\end{array}$ & $\begin{array}{l}-19.6 * * * \\
(-4.0)\end{array}$ & 0.765 & 11.0 \\
Norway & $93.7^{* * *}$ & -16.3 & $-30.1^{* * *}$ & 0.709 & 13.0 \\
& $(16.2)$ & $(-2.2)$ & $(-5.2)$ & & 6.5 \\
Sweden & $98.2^{* * *}$ & $-13.3^{* *}$ & $-29.2 * * *$ & 0.893 & \\
\hline
\end{tabular}

See note Table 4. 
some time, but not forever. In the mid-eighties the EC started to follow the path of the Scandinavian countries. The first sign was the reduction of surplus production in the dairy sector. In this sector the EC had built up a dominant position on the world market, so that the increase in the exports became negative for the EC itself. In 1988 further decisions were made in the $\mathrm{EC}$ which also followed the lines which were visible in Scandinavia much earlier: further cutbacks of production, introduction of other instruments and more emphasis on rural, regional and nature conservation aspects.

The explicit and implicit offers of the EC in the GATT-negotiations go in the direction of less support for the agricultural sector and, especially, less emphasis on exports subsidies. Connected with these negotiations EC-commissioner McSHARRY has launched proposals in which further regionalisation of the agricultural policy plays a prominent role. The peripheral regions of the EC do support these proposals warmly. However, also in the regions with rational agricultural production - the regions which have profited long from the CAP - there is some acceptance of the proposals. In those regions the possible changes in the CAP are seen as undesirable but inevitable and treated as a trade-off between market entrance and support funds.

The future picture for the CAP then is quite clear and can be described with competition, regionalisation of support and less support for exports. So, the EC started to change its agricultural policy much later than the Scandinavian countries due to its different politi- cal and trading power, but follows the same marching route.

\section{Evaluation of the results}

The EC agricultural policy has had farreaching consequences for the Scandinavian countries. The countries lost market outlets for their production surpluses. From the beginning of the seventies onwards the Scandinavian countries have gradually been trying to reshape their own protectionistic agricultural policy in order to cope with the external pressure. The result has been somewhat less emphasis in price policy, and relatively more in specific measures for certain regions and certain groups of farmers: regionalization and categorization.

It took another 10-15 years before the EC seriously had to take the external pressure into account, primarily because of the market changes caused by itself. The policy answer has been more or less the same as in the Scandinavian countries: a move away from price policy and to specific measures.

The recent GATT-negotiations will possibly lead to a further increase of the external pressure on both the EC and Scandinavian countries. It is to be expected that the tendency of changing agricultural policy in regional, rural and environmental policy directions will be continued or even enforced then.

Acknowledgements. The article is largely based on a study made for the Landbouw-Economisch Instituut LEI, The Hague, The Netherlands (Kunmonen, 1991). The authors thank Jaap Post, head of general economics department at the LEI, for fruitful comments. 


\section{References}

Anderson, K. and Tyers, R. 1984. European Community Grain and Meat Policies: Effects on International Prices, Trade and Wellfare. European Review of Agricultural Economics 11: 366-394.

Balassa, B. 1965. Trade Liberalization and 'Revealed' Comparative Advantage. Manchester School of Economic and Social Studies 33: 99-124.

Bureau of Agricultural Economics 1985. Agricultural Policies in the European Community. Their origins, nature and effects on production and trade. Policy Monograph No. 2, Canberra.

Commission of the European Communities. The Agricultural Situation in the Community. Brussels/Luxembourg, var.years.

Gulbrandsen, O. and LindBeck, A. 1969. The Economics of the Agricultural Sector. Stockholm: Almqvist and Wiksell.

JoHns, R. A. 1985. International Trade Theories and the Evolving International Economy. London: Weidenfeld and Nicholson.

Kettunen, L. and Sumelius, J. (eds.) Produktionsbe- gränsningen i Norden. Utredning/rapport 34 . Nordiske Jordbruksforskeres Forening.

KNox, F. 1986. The Trade Diversion Effect of the Common Agricultural Policy. Report No. 1. London: Trade and Tariffs Research.

Kunmonen, T. 1991. The Consequences of the EC Agricultural Policy for Scandinavian Agriculture - A Trade Approach. Onderzoekverslag 76. Den Haag: Landbouw-Economisch Instituut.

Nordisk Ministerråd 1989. Jordbrukspolitiken i de Nordiska Länderna; målen, medlen och konsekvenserna. No. 15, Kobenhavn.

OeCD 1987. National Policies and Agricultural Trade. Paris.

Strijker, D. and Kunmonen, T. 1988. The Consequences of the Agricultural Policy of the EC for the Rural Areas of the Nordic Countries. Paper for the 28th European Congress of the Regional Science Association, Stockholm.

Ms received March 27, 1991

\section{SELOSTUS}

\section{EY:n ja Skandinavian maiden välisen maatalouskaupan muutosten syyt ja seuraukset}

\section{Tuomas Kuhmonen}

Pellervo Economic Research Institute,

Revontulentie 8, 02100 Espoo, Finland

\section{Dirk Strijker}

State University Groningen, P.O.Box 800, 9700 AV Groningen, The Netherlands

Valtaosa tutkimuksista EY:n yhteisen maatalouspolitiikan (CAP) vaikutuksista kolmansien maiden kanssa käytävään kauppaan käsittelee vaikutuksia joko suuriin vientimaihin tai kehitysmaihin. Tässä artikkelissa tarkastellaan näită vaikutuksia Skandinavian maiden - Suomen, Norjan ja Ruotsin - năkőkulmasta.

Tutkimusperiodina oli 1960-1985 ja tutkimusaineistona käytettiin Skandinavian maiden ulkomaankauppatilastoja. Tutkimuksessa käytetyt keskeiset muuttujat olivat EY:n osuus Skandinavian maiden maatalous- ja elintarviketuonnissa ja - viennissă sekă näihin perustuvat "paljastetun suhteellisen edun"' (RCA) ja "suhteellisen markkinavoiman" (RTP) indeksit.
EY:n yhteisen maatalous- ja kauppapolitiikan käyttöönotto 1960-luvun alkupuolella sekä yhteisön merkittävä laajentuminen vuonna 1973 ovat merkinneet EY:n markkinoiden suhteellista sulkeutumista Skandinavian(kin) maatalousvienniltä. Samanaikaisesti EY:n osuus Skandinavian maataloustuonnissa on kasvanut. Tuoteryhmittäin tarkasteltuna Skandinavian maat ovat menettăneet markkinavoimaansa suhteessa EY:öön eniten perusmaataloustuotteissa. EY on kyennyt lisäămäăn keskinäistă suhteellista markkinavoimaansa maataloustuotteissa muihin tuotteisiin verrattuna.

EY:n ylijäämien alentamien vientihintojen ja keskinăisen kaupan muutosten vuoksi Skandinavian maat ovat 
joutuneet turvautumaan tuotannonohjaus- ja -rajoituskeinoihin aikaisemmin ja/tai radikaalimmin kuin resursseiltaan ja kooltaan suurempi EY. Politiikkatasolla huoltovarmuuden käsite on painottunut, maatalouspolitiikka ja -tuki spesifioitunut sekä itse maatalouspolitiikan käsite ja keinovalikoima laajentunut vastauksena tuotan- non tasapainottamisen ja uudelleensuuntaamisen paineisiin. EY näyttää seuraavan näissă suhteissa Skandinavian maiden esimerkkiä, tosin viiveisesti. Skandinavian maiden kannalta katsoen EY on toiminut maatalouden tuotanto- ja rakennemuutoksen kiihdytta̋jänä. 